\title{
Determination of Copper Using Supramolecular Solvent-based Microextraction for Food, Spices, and Water Samples Prior to Analysis by Flame Atomic Absorption Spectrometry
}

\author{
Nebiye Ozkantar ${ }^{a}$, Mustafa Soylak ${ }^{b}$, and Mustafa Tuzen ${ }^{a, *}$ \\ a Tokat Gaziosmanpasa University, Faculty of Science and Arts, Chemistry Department, \\ 60250 Tokat, Turkey \\ b Erciyes University, Faculty of Sciences, Department of Chemistry, \\ 38039 Kayseri, Turkey
}

\section{INTRODUCTION}

Copper $(\mathrm{Cu})$ is one of the most important essential trace elements. Foods such as olives, almonds, beans, grapes, and wheat contain copper. Copper plays an important role in the metabolism and is very active for some biological processes, especically in the synthesis of red blood cells (1-4). The metal is also necessary for enzymes whose duties are renewing body tissues and contribute to the strength of the bone structure. It takes charge in protein synthesis and energy production. Deficiency of copper results in anemia, decreased body resistance to illnesses, weakness, even forming scars on skin and causing eczema. Despite the fact that copper is an essential trace element when it is taken at high levels, it can also produce toxic effects. For instance, causing harm to organs such as the brain and pancreas, and mental and physical sickness such as depression, high blood pressure, and can$\operatorname{cer}(5,6)$.

Copper also has industrial uses due to its high electrical and thermal conductivities, good durability and ductility, with perfect resistance to corrosion. Hence, can become a very real concern for environmental pollution in wastewater and the environment in general. Thus, monitoring of trace

\footnotetext{
*Corresponding author.

:E-mail: mustafa.tuzen@gop.edu.tr

Tel: +903562521585
}

\section{ABSTRACT}

A simple and sensitive supramolecular solvent microextraction method was developed for the separation, preconcentration and determination of trace levels of copper in food and environmental samples. The supramolecular solvent system consists of tetrahydrofuran (THF) and undecanol and was used as an extraction solvent for the microextraction procedure of $\mathrm{Cu}(\mathrm{II})$. A supramolecular solvent microextraction procedure for copper(II) as its 5-methyl-4-(2-thiazolylazo) resorcinol (5-ME-TAR) complex was established prior to microsampling flame atomic absorption spectrometric determination. The influence of various analytical parameters including $\mathrm{pH}$, solvent type and volume, amount of 5-methyl-4-(2-thiazolylazo) resorcinol, and centrifugation time were investigated. The effects of certain alkali, alkaline earth, and transition metal ions on the quantitative extraction of copper(II) were also studied.

The proposed supramolecular solvent-based microextraction procedure exhibits a limit of detection (LOD) of $1.4 \mu \mathrm{g} \mathrm{L}^{-1}$ and a limit of quantification (LOQ) of $4.6 \mu \mathrm{g} \mathrm{L}^{-1}$. A preconcentration factor of 60 was obtained and the relative standard deviation was $2.78 \%$. The method was validated by the analysis of certified reference materials and applied to food, spices, and water samples. levels of copper in samples from industrial wastewater, biological and food samples (7) is very important. Copper is also obtained from sulfur ore requiring negative enrichment, an expensive process and of concern for environmental pollution.

Because of the low levels of copper in food, water, and ores as well as interference from matrix components, reliable and sensitive analytical methods are required for its determination (8). For this purpose, analytical methods such as atomic absorption spectrometry (FAAS), X-ray fluorescence (XRF), neutron activation analysis (NAA), inductively coupled plasma atomic emission spectrometry (ICP-AES), electrothermal atomic absorption spectrometry (ETAAS), voltammetry and inductively coupled plasmamass spectrometry (ICP-MS) have been commonly used (9).

However, for trace metals analysis with any of the above methods, an enrichment procedure has to be applied. In this study, flame atomic absorption spectrometry (FAAS) has been selected which also requires a sample preparation method. Since the concentration of copper is generally very low in environmental, food, ore samples and due to matrix effects, a number of effective separation and enrichment methods have been developed (10). For instance, adsorption, cloud point extraction (CPE), liquid-liquid extraction (LLE). 
These methods have the disadvantage of requiring considerable amounts of chemical solvents, have small preconcentration factor, and are time-consuming. Hence, microextraction methods such as dispersive liquid-liquid microextraction (DLLME), supramolecular solventbased microextraction (SS-LLME), and single drop microextraction (SDME) have become popular. In this study, the supramolecular solvent-based microextraction process was used for the separation/preconcentration of trace levels of copper.

The suprameolecular liquid phase microextraction is based on the self-assembly process of two or more solvents having a long carbon chain containing hydroxyl and carboxylic acid groups in their structure. Supramolecular solvent liquid-liquid microextraction (SSLLME) occurs at a molecular and nono-sized level from a homogenized solution containing amphilic groups (11-13). Supramolecular solvents create a perfect reaction setting for the extraction process. Thus, these solvents composed of nano-sized micelles interact more with the analyte. They provide high extraction efficiency. The method is generally applied to the extraction of metals and hydrophobic organic compounds in environmentl and biological aqueous samples (11-13). It is environmentally friendly, with a short exraction time, no harmful waste generation, easily applicable, accessible, and a fast low-cost liquid phase extraction technique (14).

With this microextraction method, the high efficient ligands are sorbents to remove the copper ions from the aqueous solution. 5-ME-TAR is one of the ligands containing a resorcinol scaffold. Its respective formula and molecular weight are $\mathrm{C}_{10} \mathrm{H}_{9} \mathrm{~N}_{3} \mathrm{O}_{2} \mathrm{~S}, 235.26$ $\mathrm{g} / \mathrm{mol}$. The 5-ME-TAR can be applied for the determination of various transition metal ions, such as $\mathrm{Cu}^{2+}, \mathrm{Pd}^{2+}, \mathrm{Ni}^{2+}, \mathrm{Zn}^{2+}, \mathrm{Hg}^{2+}$, etc.
The complexes of 5-ME-TAR with these metals have a higher molar absorptivity $(15,16)$. The 5-ME-TAR resorcinol ligand with many nitrogen and oxygen donor atoms binds the metal cations (17).

In this work, a new, simple, and rapid supramolecular system procedure has been established for the separation and preconcentration of $\mathrm{Cu}$ (II) with 5-methyl-4-(2thiazolylazo) resorcinol (5-MeTAR) complex before determination by microsampling flame atomic absorption spectrometry. The analytical parameters for quantitative extraction were optimized, and recoveries up to $95 \%$ were achieved. In addition, the method was validated by the analysis of certified reference materials and applied to food and water samples.

\section{EXPERIMENTAL}

\section{Instrumentation}

A PerkinElmer AAnalys ${ }^{\mathrm{TM}} 300$ flame atomic absorption spectrometer from (PerinElmer, Inc., Shelton, CT, USA) was used for this study. The instrument was equipped with an air-acetylene flame with a $10 \mathrm{~cm}$ long slot burner head. Hollow cathode lamps were used for copper. A PHS-3C pH meter (pH-900, Ankara, Turkey) with a combined glass electrode was utilized to determine the $\mathrm{pH}$ values. The distilled water was obtained with a Millipore Milli-Q ${ }^{\circledR}$ system $(18 \mathrm{M} \Omega-\mathrm{cm}$ resistivity, Millipore Corporation, Bedford, MA,

TABLE I

Instrumental Operating Conditions Used for FAAS Analysis

\begin{tabular}{ll}
\hline Element & $\mathrm{Cu}$ \\
Wavelength & $324.8 \mathrm{~nm}$ \\
Slit width & $0.7 \mathrm{~nm}$ \\
Lamp current & $15 \mathrm{~mA}$ \\
Flame conditions: & \\
$\quad$ Air & $9.5 \mathrm{~L} / \mathrm{min}$ \\
Acetylene & $2.3 \mathrm{~L} / \mathrm{min}$ \\
\hline
\end{tabular}

USA). Also, a model ALC PK 120 centrifuge (Buckinghamshire, England) and a Vortex mixer (Wiggen Hauser, Selangor, Malaysia) were used. The instrumental parameters for flame atomic absorpiton spectrometry analysis are listed in Table I.

\section{Reagents and Standard Solutions}

The diluted standard solutions were prepared from a stock standard copper solution of $1.00 \mathrm{mg} \mathrm{L}^{-1}$ $\mathrm{Cu}\left(\mathrm{NO}_{3}\right)_{2}$ in $\mathrm{HNO}_{3}$ was obtained from Merck, Darmstadt, Germany. Working solutions were prepared daily from the stock solutions by serial dilution with distilled water (18). A solution of 5-methyl-4-(2thiazolyazo) resorcinol (5-ME-TAR) was prepared in ethanol (Aldrich 95\%). In addition (5-ME-TAR) solution of $0.025 \%$ was prepared by dissolving $0.025 \mathrm{~g}$ of (5-ME-TAR) in $100 \mathrm{~mL}$ of ethanol. Within the $\mathrm{pH}$ range of 4 to 8 , the $\mathrm{pH}$ values were adjusted by addition of HAc-NaAc, borate and ammonia buffer solutions. Accuracy of the method was studied by examining the standard analytical reference materials TMDA 53.3 (Canada Lake Water) and NCSZC73032 Celery (P.R. China). Also, 0 - $8 \mu \mathrm{g} / \mathrm{L}$ standard solutions were used. All chemicals and analytical grade solutions were prepared in deionized water.

\section{Procedure}

An amount of $4 \mu \mathrm{g} \mathrm{Cu}(\mathrm{II})$ was taken into a 50-mL centrifuge tube, then $2 \mathrm{~mL}$ of acetate buffer solution was added to adjust the sample $\mathrm{pH}$ to 6 . After $\mathrm{pH}$ regulation, $400 \mu \mathrm{L}$ THF and $200 \mu \mathrm{L}$ undecanol were added quickly to the Cu(II) sample solution to form the supramolecular solvent. After these steps, the sample solution of $\mathrm{Cu}(\mathrm{II})$ was sonicated for 3 minutes, and a cloudy solution was obtained. After continuing the ultrasonication process, the supracellar solvent solution passing through the molecular 
casing was blurred. The cloudy solution was centrifuged at 4000 rpm for 10 minutes. Then, the solvent phases were completely separated from the aqueous phase and formed a solvent solution in the upper phase. The lower water phase was eliminated with an injector. After the liquid phase was removed from the solution, the remaining phase volume was between 200 and $300 \mu \mathrm{L}$. The supramolecular solvent (about 200-300 $\mu \mathrm{L}$ ) was completed to $500 \mu \mathrm{L}$ with ethanol. The final solution was optimized using the developed microextraction method and analyzed by flame atomic absorption spectrometry.

\section{RESULTS AND DISCUSSION}

\section{Effect of $\mathbf{p H}$}

Since extraction of the material from the water phase to the extraction phase depends on the $\mathrm{pH}$ value of the medium at the trace level, the model solutions were prepared at different $\mathrm{pH}$ values (4-8) with the help of a buffer solution in order to determine the optimum $\mathrm{pH}$ range for the quantitative extraction of copper. Therefore, all subsequent studies were performed at $\mathrm{pH} 6$. Later, the microextraction method was applied to the specimens using the atomic absorption spectrometer. Quantitative recoveries ( $\mathrm{R} \geq 95 \%$ ) were obtained for copper at $\mathrm{pH} 6$. The optimum sample solution $\mathrm{pH}$ was chosen at 6 , and the subsequent work was continued at $\mathrm{pH} 6$ (Figure 1).

\section{Effect of Volume Ratio of Undecanol and THF}

The supramoleculer solvent is obtained by mixing species that have a long carbon chain, including carboxylic acid (-COOH) and the hdroxyl $(-\mathrm{OH})$ group with organic solvents such as THF or tetrabutyl-ammonium. Initially, we decided which supramolecular solvents to use for the preconcentration of copper. For this reason, preconcentration of copper, the effects of non-molecular, water-immiscible and micelle-forming organic solvents were generated. After this parameter, the amount of supramoleculer solvents, which have been chosen to obtain the best recovery value, were investigated. The supramolecular solvent-based microextraction method with undecanol was selected since the recovery values of $95 \%$ or more were obtained.

One of the most important parameters is the volume of extraction solvent that seriously affects the efficiency of extraction performance (19). A volume of 50-400 $\mu \mathrm{L}$ undecanol was prepared before determining the optimal volume to be present in the supramolecular solvent. The results are given in Figure 2. As can be seen, the quantitative undecanol volume was $200 \mu \mathrm{L}$

In addition, the influence of THF volume, required to be present in the supramolecular solvent, was studied for the recovery of copper. For this, the supramolecular solubilizers were prepared in which the volume of undecanol was fixed to $200 \mu \mathrm{L}$ and the volume of THF was changed. A THF volume between 200-600 $\mu \mathrm{L}$ was chosen, and the final optimum THF volume selected was $400 \mu \mathrm{L}$. The volume of tetrahydrofuran was kept constant at $0.4 \mathrm{~mL}$ (Figure 3).

As a result, further experiments were carried out using $200 \mu \mathrm{L}$ of undecanol and $400 \mu \mathrm{L}$ of THF, followed by separation-enrichment by microextraction with the supramolecular solvent.

\section{Effect of Amount of Ligand}

For this parameter, the optimum amount of 5-methyl-4-(2-thiazolylazo) resorcinol (5-ME-TAR) ligand was investigated. For this, the extraction was carried out by

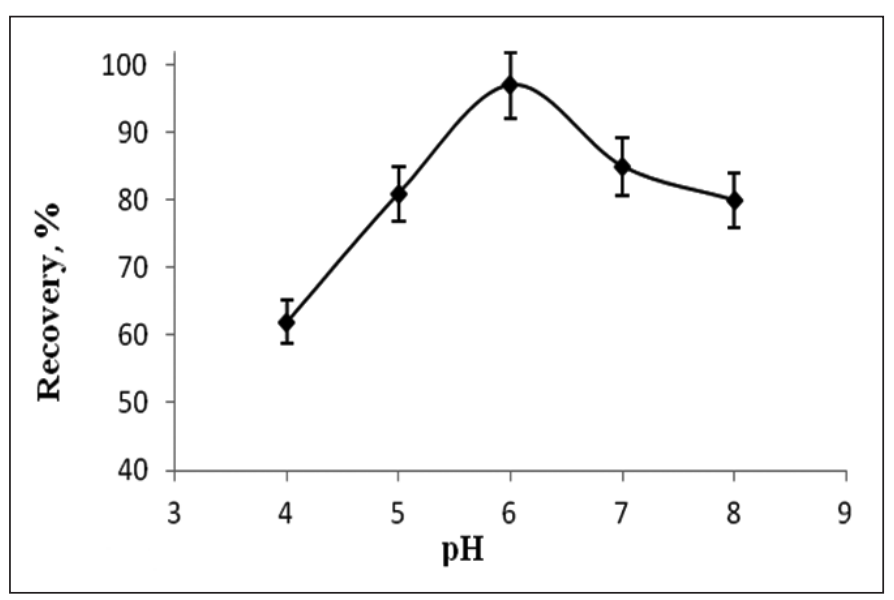

Fig. 1. Effects of $p H$ on the recoveries of copper $(N=3)$.

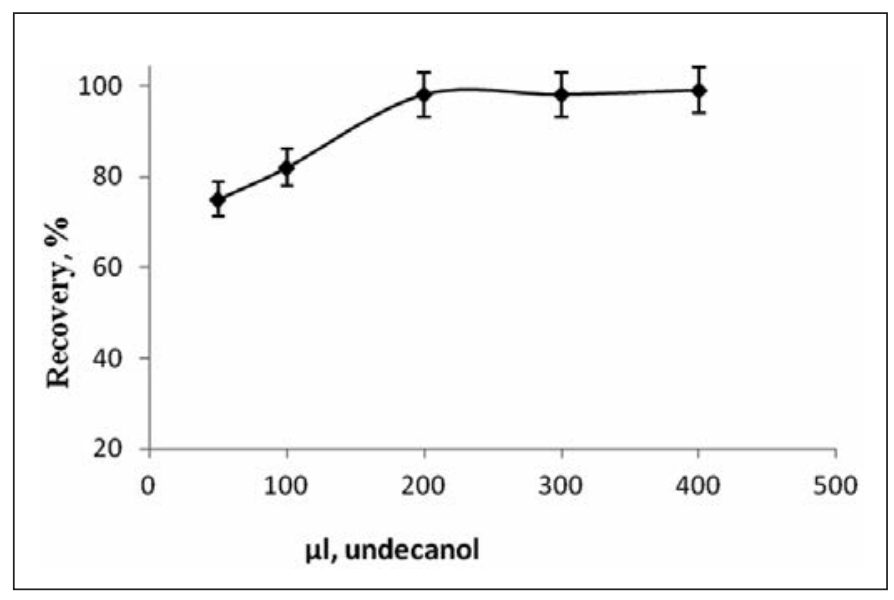

Fig. 2. Effects of undecanol volume on the recoveries of cop$\operatorname{per}(N=3)$. 
adding the amount of ligand from 0 to $0.25 \mathrm{mg}$ in sample solutions. It was found that the preconcentration of copper was quantitative using above $0.2 \mathrm{mg}$ of the ligand and the recovery values were $96-97 \%$. Thus, $0.2 \mathrm{mg}$ of the ligand was chosen for all subsequent extractions. The experimental results are shown that Figure 4.

\section{Effect of Sample Volume and Centrifugation Time}

The supramolecular solventbased microextraction method was carried out in the range of $10-40 \mathrm{~mL}$ of sample volume at the optimized conditions of $\mathrm{pH} 6$, amount of ligand $0.2 \mathrm{mg}(0.025 \%)$, and final volume of $0.5 \mathrm{~mL}$ in order to calculate the preconcentration factor, as shown in Figure 5. Although the recovery values for the $30 \mathrm{~mL}$ sample volume were quantitative, the recovery values were beginning to decrease when the sample was prepared with a higher volume value. Thus, the preconcentration factor was calculated as 60 , considering the last volume was $500 \mu \mathrm{L}$.

The effect of centrifugation time was also investigated in the range of 5-15 minutes. Quantitative recovery of $\mathrm{Cu}$ (II) was achieved in 10 minutes. A centrifugation speed and time of $4000 \mathrm{rpm}$ and $10 \mathrm{~min}-$ utes, respectively, were selected for further experiments for $\mathrm{Cu}(\mathrm{II})$.

\section{Matrix Effects}

The effects of alkaline, earth alkaline, and some anions cause matrix effects in the flame atomic absorption spectrometric determinations of trace level copper. Therefore, researching the matrix effects of foreign ions are one of the most important parameters. In addition, this parameter verifies the selectivity of the method for the preconcentration and separation of the $\mathrm{Cu}(\mathrm{II})$ ions. The tolerance concentrations of each of the foreign ions mentioned before were investigated and the recovery values were calculated. The obtained results are summarized in Table II.

\section{Analytical Performance}

The analytical parameters of the supramolecular solvent-based microextraction method for $\mathrm{Cu}$ (II) using the optimum conditions are shown in Table III. Also, the analytical performance criteria such as limit of quantification (LOQ), limit of detection (LOD), relative stan-

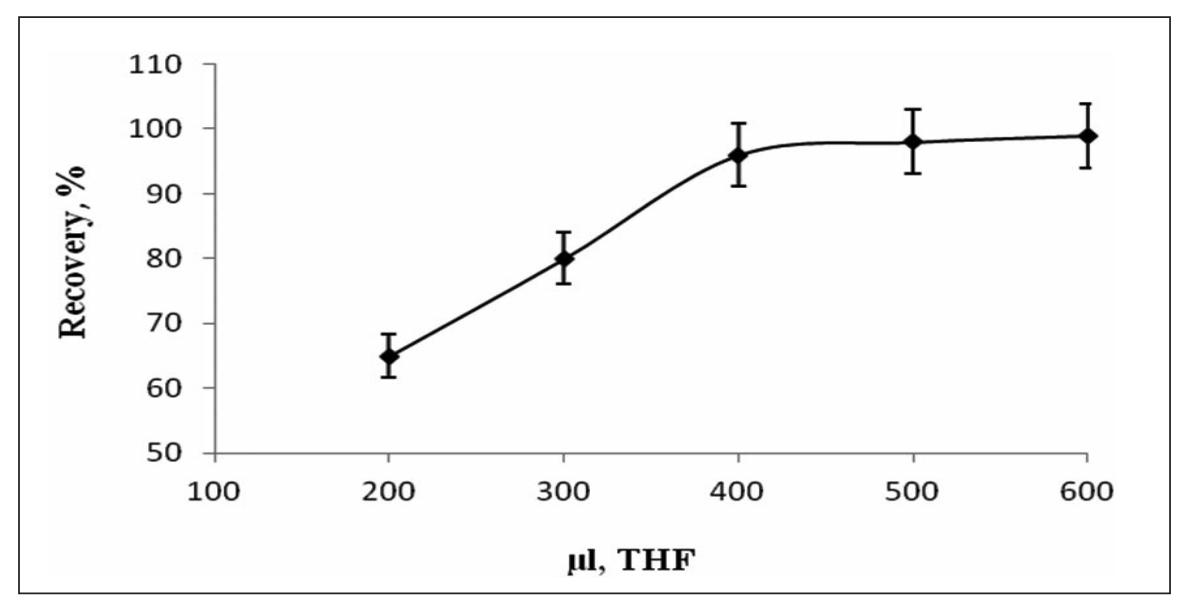

Fig. 3. Effects of THF volume on the recoveries of copper $(N=3)$.

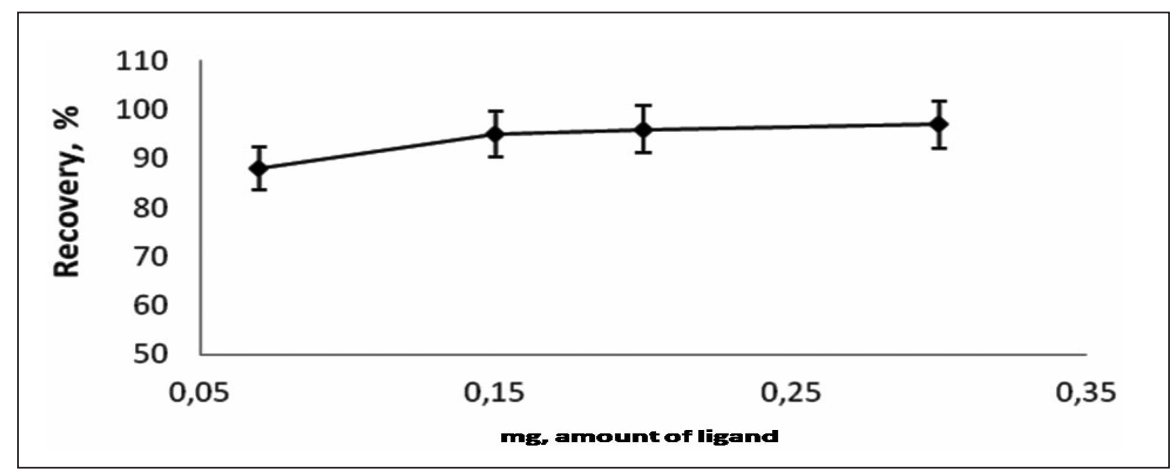

Fig. 4. Effects of 5-methyl-4-(2-thiazolylazo) resorcinol (5-MeTAR) amount on the recoveries of copper. $(N=3)$.

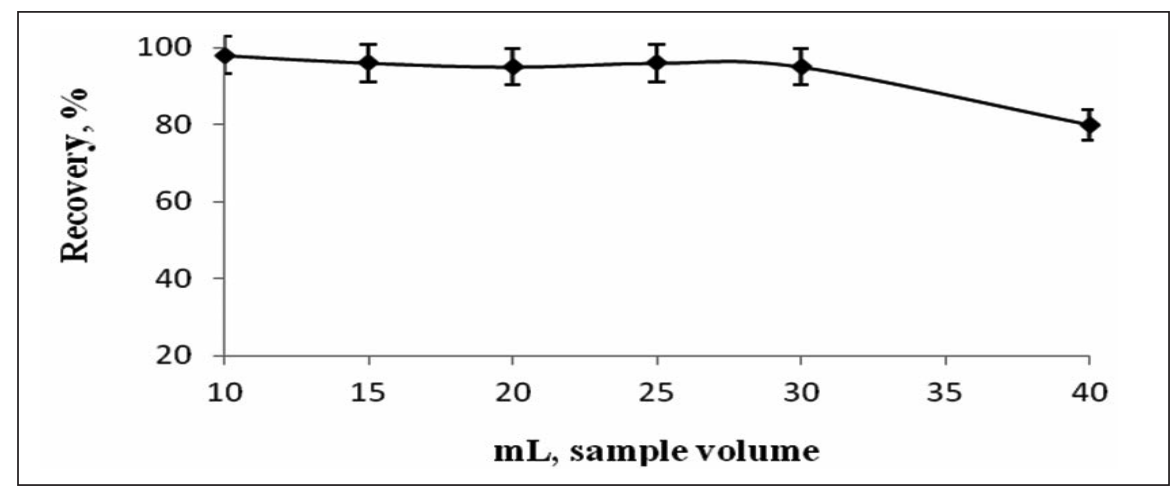

Fig. 5. Effects of sample volume on the recoveries of copper $(N=3)$. 
dard deviation (RSD), correlation co-efficient $\left(\mathrm{R}^{2}\right)$, and the preconcentration factor (PF) for copper were examined under the optimized experimental conditions. Furthermore, quantitative recovery values fall below $10 \mathrm{~mL}$, and above $30 \mathrm{~mL}$ was not obtained. The developed supramolecular solvent-based microextraction procedure exhibits a limit of detection (LOD) of 1.4 $\mu \mathrm{g} \mathrm{L}^{-1}$ (LOD by using the $3 \mathrm{~s} / \mathrm{m}$ formula) and a limit of quantification (LOQ) of $4.6 \mu \mathrm{g} \mathrm{L}^{-1}$ (LOQ was calculated by using the $10 \mathrm{~s} / \mathrm{m}$ formula). The preconcentration factor was found at 60 (20). The linear calibration curve was obtained using equation $\mathrm{A}=0.1947 \mathrm{C}-0.004$, $\mathrm{r}^{2}=0.9993[\mathrm{~A}=$ mean absorbance and $\mathrm{C}=$ the concentration of $\mathrm{Cu}(\mathrm{II})$ $\mu \mathrm{g} \mathrm{L^{-1 }}$.

Precision is important for the preconcentration of copper. Because of this, the relative standard deviation (RSD), determined from standard solution of copper was $2.78 \%(\mathrm{RSD}=\mathrm{s} / \mathrm{x})$.

\section{Analysis of Certified Samples}

The accuracy of the proposed method was verified using the analysis of two certified reference

TABLE II

Influences of Some Foreign Ions on the Recoveries of $\mathrm{Cu}$

\begin{tabular}{|c|c|c|c|}
\hline Foreign Ions & Added As & Concentration $\left(\mathrm{mg} \mathrm{L}^{-1}\right)$ & Recovery (\%) \\
\hline $\mathrm{Na}^{+}$ & $\mathrm{NaNO}_{3}$ & 2500 & $103 \pm 1^{\mathrm{a}}$ \\
\hline $\mathrm{K}^{+}$ & $\mathrm{KCl}$ & 2500 & $98 \pm 1$ \\
\hline $\mathrm{Mg}^{2+}$ & $\mathrm{Mg}\left(\mathrm{NO}_{3}\right)_{2} \cdot 6 \mathrm{H}_{2} \mathrm{O}$ & 2000 & $100 \pm 1$ \\
\hline $\mathrm{Ca}^{2+}$ & $\mathrm{Ca}\left(\mathrm{NO}_{3}\right)_{2} \cdot 4 \mathrm{H}_{2} \mathrm{O}$ & 2000 & $100 \pm 0$ \\
\hline $\mathrm{Zn}^{2+}$ & $\mathrm{Zn}\left(\mathrm{NO}_{3}\right)_{2} \cdot 6 \mathrm{H}_{2} \mathrm{O}$ & 20 & $97 \pm 1$ \\
\hline $\mathrm{Mn}^{2+}$ & $\mathrm{Mn}\left(\mathrm{NO}_{3}\right)_{2} \cdot 4 \mathrm{H}_{2} \mathrm{O}$ & 20 & $95 \pm 0.5$ \\
\hline $\mathrm{Cr}^{3+}$ & $\mathrm{Cr}\left(\mathrm{NO}_{3}\right)_{3} \cdot 9 \mathrm{H}_{2} \mathrm{O}$ & 20 & $98 \pm 2$ \\
\hline $\mathrm{Cd}^{2+}$ & $\mathrm{Cd}\left(\mathrm{NO}_{3}\right)_{2} \cdot 4 \mathrm{H}_{2} \mathrm{O}$ & 20 & $102 \pm 1$ \\
\hline $\mathrm{Cl}^{-}$ & $\mathrm{KCl}$ & 2500 & $98 \pm 1$ \\
\hline $\mathrm{SO}_{4}{ }^{2-}$ & $\mathrm{Na}_{2} \mathrm{SO}_{4}$ & 2000 & $101 \pm 1$ \\
\hline
\end{tabular}

${ }^{\mathrm{a}}$ Mean \pm standard deviation.

TABLE III

Optimum Conditions for Supramolecular Solvent-based Microextraction of $\mathrm{Cu}$

$\mathrm{pH}$

Supramolecular solvent (THF:undecanol)

5-methyl-4-(2-thiazolylazo) resorcinol (5-MeTAR)

Sample volume

Final volume

Centrifugation speed and time
6

2:1 (400 $\mu \mathrm{L}: 200 \mu \mathrm{L})$

$0.2 \mathrm{mg}$

$30 \mathrm{~mL}$

$500 \mu \mathrm{L}$

Table IV

Application for $\mathrm{Cu}$ in CRMs

\begin{tabular}{lrcc}
\hline CRMs & Certified Value & Observed Value & Recovery (\%) \\
\hline TMDA 53.3 & $312 \mu \mathrm{g} \mathrm{L}^{-1}$ & $307 \pm^{\mathrm{a}} 0.5 \mu \mathrm{g} \mathrm{L}^{-1}$ & 98 \\
NCSZC73032 Celery & $\mathbf{8 . 2 \pm 0 . 4 \mu \mathrm { g } \mathrm { g } ^ { - 1 }}$ & $\mathbf{8 . 1 4 \pm 1 . 8 \mu \mathrm { g } \mathrm { g } ^ { - 1 }}$ & 99 \\
\hline
\end{tabular}

\footnotetext{
${ }^{\mathrm{a}}$ Mean \pm standard deviation.
}

\section{Atomic Spectroscopy \\ 1 Vol. 40(1), Jan./Feb. 2019}

materials (CRMs): TMDA 53.3 Food (China National Analysis Center, P.R. China) and NCSZC73032 Celery (National Water Research Institute, Canada). Initially, $2 \mathrm{~mL}$ of TMDA 53.3 was prepared and added to the sample solution. Then, the developed preconcentration method was applied at optimum conditions ( $2 \mathrm{~mL}$ buffer solution, $0.2 \mathrm{mg}$ 5-ME-TAR ligand, $\mathrm{pH} 6$, and $1: 2$ undecanol-THF supra-molecular solvent). The CRM NCSZC 73032 Celery sample was analyzed, $75 \mathrm{mg}$ placed into a beaker and $10 \mathrm{~mL}$ $\mathrm{HNO}_{3}$ added, then evaporated to dryness. The mixture was allowed to cool, and then $5 \mathrm{~mL}$ of $\mathrm{HNO}_{3}+$ $5 \mathrm{~mL} \mathrm{H}_{2} \mathrm{O}_{2}$ were added and evaporated to dryness. The standardized reference material that was solubilized was extracted with $5 \mathrm{~mL}$ of distilled water. Then the supramolecular solvent was added, and the solution completed to $10 \mathrm{~mL}$ with distilled water. After these steps, the proposed supramolecular solvent-based microextraction method was applied. The calculated values are listed on Table IV. These values show that this method proves the accuracy of the microextraction method.

\section{Analysis of Food and Water Samples}

Different real samples, such as food and water, were analyzed by the developed microextraction procedure. The method proposed for addition/recovery has been applied to tap water, lake water, macaroni, opium poppy, thyme, and bread.

An amount of $1 \mathrm{~g}$ of each real sample (macaroni, opium poppy, thyme, and bread) was put into respective $50-\mathrm{mL}$ beakers. Then, $10 \mathrm{~mL} \mathrm{HNO}_{3}$ was added for sample solubilization and evaporated to dryness with a manual heater. The dissolved and evaporated samples were left standing until cooled. At the end of this operation, $5 \mathrm{~mL}$ $\mathrm{HNO}_{3}$ and $5 \mathrm{~mL} \mathrm{H} \mathrm{O}_{2}$ were added to the samples, and evaporated in 
TABLE V Application of Present Method to Food Samples

\begin{tabular}{lccr}
\hline Samples & $\begin{array}{c}\text { Added } \\
(\mu \mathrm{g} / \mathrm{g})\end{array}$ & $\begin{array}{c}\text { Found } \\
(\mu \mathrm{g} / \mathrm{g})\end{array}$ & $\begin{array}{c}\text { Recovery } \\
(\%)\end{array}$ \\
\hline Macaroni & 0.0 & $0.17 \pm \pm^{\mathrm{a}} 0.20$ & - \\
& 1.0 & $1.16 \pm 0.14$ & 99 \\
Opium poppy & 0.0 & $0.16 \pm 0.03$ & - \\
& 1.0 & $1.17 \pm 0.06$ & 10199 \\
Thyme & 2.0 & $2.14 \pm 0.03$ & 99 \\
& 0.0 & $\mathrm{~N} . \mathrm{D} .{ }^{\mathrm{b}}$ & - \\
\multirow{2}{*}{ Bread } & 1.0 & $0.99 \pm 0.03$ & 99 \\
& 1.5 & $1.44 \pm 0.05$ & 95 \\
& 0.0 & $0.12 \pm 0.10$ & - \\
& 1.0 & $1.11 \pm 0.10$ & 99 \\
& 2.0 & $2.17 \pm 0.04$ & 102 \\
\hline
\end{tabular}

${ }^{a}$ Mean \pm standard deviations.

b N.D.: Not detected.

TABLE VII

Comparison of Present Method With Literature Values for Preconcentration of $\mathrm{Cu}$

\begin{tabular}{|c|c|c|c|c|c|}
\hline $\begin{array}{l}\text { Preconcentra- } \\
\text { tion Method }\end{array}$ & $\begin{array}{l}\text { Analysis } \\
\text { Method }\end{array}$ & $\mathrm{LOD}^{\mathrm{a}}$ & $\mathrm{PF}^{\mathrm{b}}$ & Samples & Ref. \\
\hline DLLME & AAS & $0.19 \mu \mathrm{g} \mathrm{L}^{-1}$ & 135 & Food, Water & 21 \\
\hline SPE & UV-Vis & $5 \mu \mathrm{g} \mathrm{L}^{-1}$ & 125 & Water & 22 \\
\hline DLLME & AAS & $0.11 \mu \mathrm{g} \mathrm{L}^{-1}$ & 60 & Water, Hair & 23 \\
\hline DLLME & HPLC & $7.9 \mu \mathrm{g} \mathrm{L}^{-1}$ & 50 & $\begin{array}{l}\text { Food, Vegetation, } \\
\text { Water }\end{array}$ & 24 \\
\hline DLLME & UV-Vis & $0.81 \mu \mathrm{g} \mathrm{mL}^{-1}$ & 5 & Water & 25 \\
\hline $\begin{array}{l}\text { Supramolecul } \\
\text { solvent-based } \\
\text { DLLME }\end{array}$ & AAS & $1.4 \mu \mathrm{g} \mathrm{L}^{-1}$ & 60 & $\begin{array}{l}\text { Food, Spices, } \\
\text { Water }\end{array}$ & $\begin{array}{l}\text { This } \\
\text { work }\end{array}$ \\
\hline
\end{tabular}

the same way until dry. These real samples were taken into tubes with distilled water after the solubilization operations were completed. Subsequently, the added/recovery operations were applied in order to implement the method. For this, three $50 \mathrm{~mL}$ sample tubes were prepared to apply the developed microextraction procedure. Then, $2.25 \mathrm{~mL}$ each of macaroni and
TABLE VI Application of Present Method to Water Samples

\begin{tabular}{llcc}
\hline Samples & $\begin{array}{l}\text { Added } \\
(\mu \mathrm{g} / \mathrm{g})\end{array}$ & $\begin{array}{c}\text { Found } \\
(\mu \mathrm{g} / \mathrm{g})\end{array}$ & $\begin{array}{c}\text { Recovery } \\
(\%)\end{array}$ \\
\hline Tap water & 0.0 & $\mathrm{~N}^{\mathrm{D}} .^{\mathrm{a}}$ & - \\
& 1.0 & $1.02 \pm^{\mathrm{b}} 0.06$ & 102 \\
& 1.5 & $1.54 \pm 0.02$ & 103 \\
Lake water & 0.0 & N.D. & - \\
& 1.0 & $1.01 \pm 0.03$ & 101 \\
& 2.0 & $1.97 \pm 0.08$ & 98 \\
\hline
\end{tabular}

${ }^{a}$ N.D.: Not detected.

${ }^{\mathrm{b}}$ Mean \pm standard deviations. the improved method was checked by the addition-recovery tests. The results listed in Table $\mathrm{V}$ for the food samples and in Table VI for the water samples show that good agreement was achieved between the added and recovered copper ions.

For this study, some previously reported methods were also investigated and compared with the proposed microextraction procedure (see Table VII). In comparison with other techniques for preconcentration of copper, the present study required a short extraction time and was performed at room temperature. Low limits of quantification (LOQ) and limits of detection (LOD) were found. A good preconcentration factor for copper was calculated at 60 , resulting from a $0.5 \mathrm{~mL}$ sample volume up to $500 \mu \mathrm{L}$ final volume. It was found that the method was optimized with simplicity, rapidity, high selectivity, and low cost and in a simple manner and little time.

\section{CONCLUSION}

This method has some advantages for the recovery of copper in food and water samples. For instance, good selectivity (there is no interaction effect in the presence of the matrix ions), the method is much simpler, faster, and low cost. Preconcentration/separation of the 
trace level copper in real samples showed high level recovery values at above $95 \%$. Furthermore, it is an environmentally sensitive method using very little organic solvent. The supramolecular solvent-based microextraction method is a rapid technique and time has no impact on the recovery of copper and extraction efficiency $(26,27)$. Also the ligand of 5-methyl-4-(2-thiazolylazo) resorcinol (5-ME-TAR) showed high affinity and good accessibility for $\mathrm{Cu}(\mathrm{II})$ ions. The matrix effects were remarkably tolerable for $\mathrm{Cu}(\mathrm{II})$. Due to these advantages, the method is practical and reliable for the preconcentration/separation of copper from environmental water and food samples.

\section{ACKNOWLEDGMENT}

The authors are grateful for the financial support of the Scientific Research Projects Unit of Gaziosmanpasa University (Project number: 2015/124).

Received May 22, 2018.

\section{REFERENCES}

1. M.I. Martin, F.A. Lopez, A. LopezDelgado, C. Pérez, and F.J. Alguacil, Rev. Metal (Madrid, Spain) 40, 324 (2003).

2. A. Vural, A. Gündogdu, I. Akpınar, and C. Baltaci, Nat. Hazards. 88, 867 (2017).

3. Z. A. Alothman, N.H. Al-Shaalan, M.A. Habila, Y.E. Unsal, M. Tuzen, and M. Soylak, Env. Mont. Ass. 187, 9 (2015).

4. 4. Z.A. Alothman, E. Yilmaz, M. Habila, and M. Soylak, Turk J. Chem. 39, 1038 (2015).

5. K. J. A. Kundig and J.G. Cowie, Mechanical Engineers' Handbook, 117, (2006).

6. H. Lipowsky and E. Arpaci, Copper in the automotive industry, Wiley Interscience, USA (2007).

7. V. Zare-Shahabadi, P. Asaadi, F.
Abbasitabarb, and A. Shirmardic. J. Braz. Chem. Soc. 28, 887 (2016).

8. S. Baytak and A. R. Türker, Talanta 65, 938 (2005).

9. M. Akter, A. Roksenul and S.H. Firoz. American J. Chem. Engineering 2, 35 (2014).

10. M. Soylak, Y. E. Unsal, E. Yilmaz and $M$. Tuzen, Food Chem. Toxicol. 49, 1796 ( 2011).

11. E. Yilmaz and M. Soylak, Talanta 126, 191 (2014).

12. A. Izadia, A. Mohebbia, M. Amiria, N. Izadib, Minerals Engineer 113, 23 (2017).

13. M. Khan, E. Yilmazi, and M. Soylak. Turk J. Chem. 41, 61 (2017).

14. M. D. Sicilia, S. Rubio. Analytica Chimica Acta 677, 108 (2010).

15. M.A. Zaitoun, A. K. El-Qisairi, K. A. Momani, H. Qaseer, and W. Alhalasah, J. Environ. Occup. Sci. 3, 154 (2014).

16. S. Thamola and S. Sompech, Materials Research Express 5, 056205 (2018)

17. D. Karthigeyan, S. Surabhi, P. Mizar, S. Soumik, A. Banerjee, S. H. Sinha, D. Dasgupta, C. Narayana, and T. Kundu, Chem. Biol. Drug Des. 87, 958 (2016).

18. M. Haji Shabania, S. Dadfarniaa, N. Nasirizadehb and M.R. Shishehboreb. Journal of Anal. Chem. 62, 46 (2007).

19. F. Aydin, E. Yilmaz, and M. Soylak, Food Chem. 243, 442 (2018).

20. Z. A. Alothman, E. Yilmaz, M. A. Habila, I. H. Alsohaimi, A. M. Aldawsari, N. M. Al- Harbi and M. Soylak, RSC. Advances 5, 106905 (2015).

21. Z. A. Othman, Y. Unsal, M. Habila, A. Shabaka, M. Tuzen, and M. Soylak, Anal. Lett. 48, 1738 (2015).

22. B. Topuz, S. M. Adanur, and A. Yalçuk, Turk J. Chem. 41, 619 (2017).

23. F. Aydin, E. Yilmaz, and M. Soylak. RSC Advances 50, 40422 (2015).

24. C. Bosch Ojeda, R.F., Sanchez, and J. M. Cano Pavon, European Scientific Journal 18, 74 (2013).

25. Y. Çaglar and T.E. Saka, Interna-

\section{Atomic Apectroscopy 1 Vol. 40(1), Jan./Feb. 2019}

tional Journal of Modern Science 3, 185 (2017)

26. S. Jafarvand and F. Shemirani, Microchim Acta. 173, 353 (2011).

27. N. Ozkantar, E. Yilmaz, M. Tüzen, and M. Soylak, Environ. Monitoring and Assess. 187, 501 (2015). 